\title{
Levels of Mercury and Polychlorobiphenyls in Bluefin Tuna from the Western Mediterranean Sea: A Food Safety Issue?
}

\author{
Monia Renzi ${ }^{1}$, Alessandro Cau ${ }^{2}$, Nicola Bianchi ${ }^{3}$, Silvano E. Focardi ${ }^{3}$ \\ ${ }^{1}$ Department of Biological and Environmental Sciences and Technologies, University of the Salento, Lecce, Italy; ${ }^{2}$ Department of \\ Life and Environmental Sciences, University of Cagliari, Cagliari, Italy; ${ }^{3}$ Department of Physical, Hearth and Environmental \\ Sciences, University of Siena, Siena, Italy. \\ Email: $\underline{\text { monia.renzi@unisalento.it }}$
}

Received November $26^{\text {th }}, 2013$; revised December $25^{\text {th }}, 2013$; accepted January $23^{\text {rd }}, 2014$

Copyright (c) 2014 Monia Renzi et al. This is an open access article distributed under the Creative Commons Attribution License, which permits unrestricted use, distribution, and reproduction in any medium, provided the original work is properly cited. In accordance of the Creative Commons Attribution License all Copyrights (c) 2014 are reserved for SCIRP and the owner of the intellectual property Monia Renzi et al. All Copyright (C) 2014 are guarded by law and by SCIRP as a guardian.

\section{ABSTRACT}

In this paper, the presence and amount of mercury and polychlorobiphenyls (PCBs) were determined in 23 bluefin tuna samples collected in the spring of 2012 in Porto Scuso (South West Sardinia, Italy) and Villa Putzu (South East Sardinia, Italy) in order to assess the current levels of these two contaminants in fish muscle and the consequent risk to humans consuming said fish. Values of polychlorobiphenyls in bluefin tuna muscle vary between 0.155 and $1.403 \mathrm{mg} / \mathrm{kg}$ f.w.; the average of PCBs in tuna muscle is $0.732 \mathrm{mg} / \mathrm{kg} \mathrm{f.w}$. With regard to PCBs the presence of more elevated concentrations is confirmed in larger fish. The results regarding mercury in muscle show an average of $0.660 \mathrm{mg} / \mathrm{kg}$ f.w. and mercury values vary between $0.140 \mathrm{f}$.w. and $2.211 \mathrm{mg} / \mathrm{kg}$ f.w.; for mercury as well, the highest concentrations were found in the largest bluefin tuna. Six samples, $26 \%$ of total, contained more than $1 \mathrm{mg} / \mathrm{kg}$ f.w., which is the maximum level set by the European Commission (EC, Regulation n. 1881/2006) for this species. Mercury, in particular methylmercury, poses a risk to public health, therefore, taking into account the important nutritional contribution that tuna fish makes to the diet, it is advisable that women of childbearing age, pregnant and breastfeeding women as well as young children strictly limit their consumption of tuna from this area of the Mediterranean.

\section{KEYWORDS}

Bluefin Tuna; Human Consumption; Mercury; PCBs

\section{Introduction}

In the last few decades, the United Nations Environment Programme has estimated that 100,000 tons of polychlorobiphenyls and 60,000 tons of mercury are dumped into the Mediterranean basin each year. The same source also indicates that 3,800 tons of lead, 36,000 tons of phosphates, 650 million tons of sewage and 129,000 tons of mineral oil are poured into the basin each year. The sea is also a major oil transportation route, and up to one million tons of crude oil are discharged annually from accidental spills, illegal bunkering and tank cleaning practices, as well as inadequate harbour facilities. Pollution also reaches the Mediterranean through its major

river systems, the Po, the Ebro, the Nile, and the Rhone, which carry substantial amounts of agricultural and industrial wastes, and the fact that 70 percent of the wastewater dumped into the Mediterranean is untreated must also be considered. As the Mediterranean is almost entirely landlocked, its waters have a very low renewal rate for 100 years [1]; this limited water exchange increases chemical residence time and allows bioaccumulation, making organisms excessively sensitive to pollution [2-7]. Moreover, geochemical and anthropogenic anomalies in mercury levels attributed to mining and industrial facilities have been described in some areas of the Mediterranean region. Studies carried out in the 
1970s and 80s allowed researchers to come up with a model by which mercury enters the trophic webs, particularly in the Province of Siena, in southern Tuscany (Mount Amiata mine), and in the Tyrrhenian Sea [8-11].

The Mediterranean marine environment has therefore been exposed to a handful of various risks which greatly threaten marine organisms. One of the most significant events occurred in the 1990s, when tens of thousands of striped dolphins died in the Mediterranean from a measles epidemic linked to very high levels of polychlorobiphenyls in the organisms $[12,13]$.

In this paper, the presence and amount of mercury and polychlorobiphenyls (PCBs) were determined in 23 bluefin tuna samples collected in the spring of 2012 in Porto Scuso (South West Sardinia, Italy) and Villa Putzu (South East Sardinia, Italy) in order to assess the current levels of these two contaminants in fish muscle and the consequent risk to humans consuming said fish. Bluefin tuna (Thunnus thynnus) is a large pelagic species heavily fished for commercial purposes, and an important resource for fish markets. Anthropic impact on this species is great due to its top position in trophic webs, thus it is very important that we know its health status and evaluate its toxicity for humans [14-17]. This work is part of a long series of studies on human exposure to environmental contaminants in the Mediterranean basin. PCBs have been previously studied in human adipose tissue samples [18-22] and human milk [23], and mercury levels have been determined in food and diet [14].

\section{Materials and Methods}

Twenty-three samples of bluefin tuna (Thunnus thynnus) caught in spring 2012 off the coasts of Sardinia in the North Western Mediterranean Sea were analysed. Samples were caught in Porto Corallo and in Portoscuso areas, respectively located in the South East and South West coast of Sardinia (Figure 1). Porto Corallo samples were caught using long lines, while Portoscuso tunas were caught in tuna nets. All samples were collected between May and June 2012. Samples were wrapped in aluminum foil that had been previously cleaned with solvents (acetone and $n$-hexane), and stored at $-20^{\circ} \mathrm{C}$ until assay.

\subsection{Mercury}

All tissue samples were stored at $-20^{\circ} \mathrm{C}$, freeze-dried and analysed for $\mathrm{Hg}$. To enable comparison of our heavy metal data with that in the literature, often calculated on a wet weight basis, aliquots of tissue were oven-dried at $105^{\circ} \mathrm{C}$ to constant weight and their percentage water content calculated. For mercury analysis, aliquots from a pool of several samples of $0.100 \mathrm{~g}$ were mineralised in PTFE digestion bombs under pressure with $3 \mathrm{~mL}$ con-

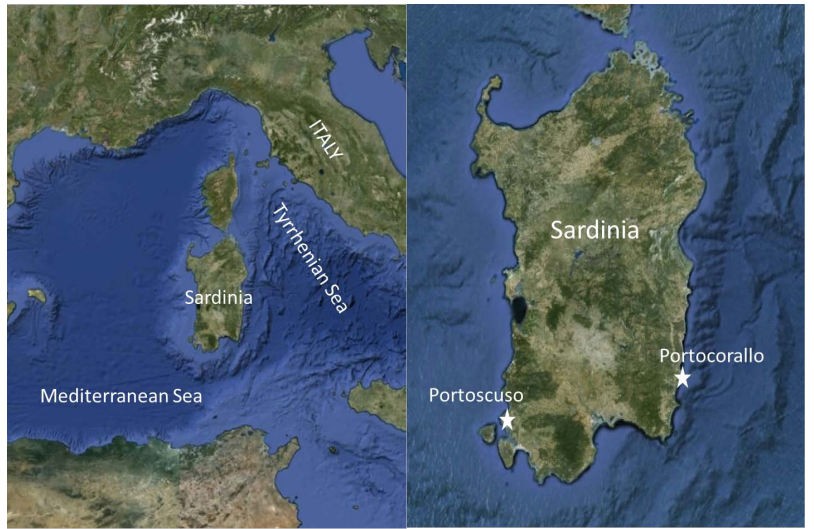

Figure 1. Sampling sites (Portoscuso and Portocorallo).

centrated $\mathrm{HNO}_{3}$ at $120^{\circ} \mathrm{C}$ for $9 \mathrm{~h}$. The resulting solutions were diluted to a final volume of $10 \mathrm{~mL}$ with ultrapure water and transferred to acid-washed sample tubes. Total mercury analysis was carried out using a cold vapour flow injection mercury system (FIMS 400, Perkin Elmer). Blanks were run during each set of tests to check the purity of the chemicals used and detect any sample contamination. All chemicals were of analytical grade. The accuracy of the results was verified with Standard Reference Materials: Bovine Liver n. 1577b (Department of Commerce National Institute of Standards and Technology, Gaithersburg, MD, USA) and Dorm-2 Tissue (Institute of Environmental Chemistry, Ottawa, Canada). Mercury concentrations are given as the mean of three replicates in $\mu \mathrm{g} / \mathrm{g}$ on a fresh weight basis.

\subsection{Polychlorobiphenyls}

All tissue samples were stored at $-20^{\circ} \mathrm{C}$ until assay. Aliquots of tissues stored at $-20^{\circ} \mathrm{C}$ were analysed following the method described by Kannan et al. [3], with some modifications. The chemicals were identified and quantified using a gas chromatograph (Perkin Elmer mod. Autosystem) equipped with ${ }^{63} \mathrm{Ni}$ electron capture detector (GC-ECD); capillary column coated with DB-5 (Supelco Inc.). Blanks were analyzed throughout the analytical procedure to check for interference and laboratory contamination. Recoveries and detection limits were described in advance and validated. PCBs were calculated as the sum of the principal congeners identified (43 congeners). Some PCB congeners were confirmed by GC/ MS (ThermoFinnigan TraceTM GC 2000/GCQ plus with ion trap detector). The gas chromatograph was equipped with an AS 2000 autosampler (ThermoFinnigan) and fitted with a Rtx-5MS capillary column (30 m, $0.25 \mathrm{~mm}$ i.d.) from Restek. GC conditions and information on target/qualifier ions are described elsewhere [3]. The procedures described above were checked for recoveries and reproducibility. Procedural blanks and reference material, 
purchased from the National Institute of Standards and Technology (NIST), were analysed for quality assurance/ quality control (QA/QC) purposes. Prior to tissue extraction, six analytical blanks were prepared using the same extraction and clean-up procedure. A solvent blank was analysed every 15 samples to check the response of the gas chromatograph (GC). A recovery standard was also evaluated by spiking samples with PCB-30, with an average recovery $>80 \%$. Concentrations were not recovery corrected. Analysis of the reference material showed a mean PCB recovery of $93.5 \%$. PCB 180 had significant blank interference. Limit of detection (LOD) was defined as the average blank $(n=4)$ plus three standard deviations (SD). When target compounds were not detected in blanks, 2/3 of the instrumental detection limit was used as the method detection limit (MDL). All qualified data (i.e. exceeding the MDL) has been blank corrected. The MDL was approximately $0.05 \mathrm{ng} / \mathrm{ml}$ for most individual components. Results are given in $\mathrm{mg} / \mathrm{kg}$ on a fresh weight basis (f.w.).

\section{Results}

This study evaluated the presence and amount of mercury and polychlorobiphenyls (PCBs) in the muscle tissue of 23 Atlantic Bluefin tuna (ABFT) samples collected in the spring of 2012 off the Sardinian coasts (Italy), in order to assess the current levels of these two contaminants in fish muscle and the consequent risk to humans consuming said fish.

Over the last decade, chemical signatures in hard structures (especially otoliths) have proven helpful in discriminating between putative bluefin tuna nursery grounds in the West Atlantic and the Mediterranean [23]. Also, many genetic markers have been used to investigate the presence of sub-panmictic populations in ABFT (Atlantic Bluefin tuna) stock in the Mediterranean Sea, and the results remained controversial [24-27]. However, two panmictic sub-populations of ABFT may be recognized from the previously cited literature: the Western Mediterranean and the Eastern Mediterranean.

Although our ABFT samples were collected both on the Western and Eastern coasts of Sardinia, they can be considered part of the same Western Mediterranean ABFT population, as the strong correlation between fork length and body weight observed in these samples also seems to confirm (Figure 2).

Results in terms of average concentrations, standard deviation and range of mercury and polyclorobyphenyls in bluefin tuna muscle are shown in Table 1.

Values of polychlorobiphenyls in bluefin tuna muscle vary between $0.155 \mathrm{mg} / \mathrm{kg}$ f.w. in a bluefin tuna of 164 cm fork length (body weight $76.9 \mathrm{~kg}$ ) and a maximum value of $1.403 \mathrm{mg} / \mathrm{kg}$ f.w. in the largest bluefin tuna
Table 1. Levels of mercury and polychlorobiphenyls in bluefin tuna muscle (SD, Standard Deviation).

\begin{tabular}{ccccc}
\hline & & Mean & SD & Range \\
\hline Fork lenght & $\mathrm{cm}$ & 198.2 & 25.9 & $137.2-252.3$ \\
Body weight & $\mathrm{kg}$ & 135.7 & 45.8 & $46.5-258.8$ \\
PCBs & $\mathrm{mg} / \mathrm{kg}$ f.w. & 0.732 & 0.354 & $0.155-1.403$ \\
Hg & $\mathrm{mg} / \mathrm{kg}$ f.w. & 0.660 & 0.585 & $0.140-2.211$ \\
\hline
\end{tabular}

studied (252 cm fork length and body weight $252 \mathrm{~kg}$ ). The average level of PCBs in tuna muscle is $0.732 \mathrm{mg} / \mathrm{kg}$ f.w. and the standard deviation is $0.354 \mathrm{mg} / \mathrm{kg}$ w.w. (Table 1). With regard to PCBs, the presence of more elevated concentrations is observed in larger fish (Figure 3), with a strong correlation between PCB levels and fork length $(\mathrm{p}<0.00003)$.

In the present study, mercury values found vary between $0.140 \mathrm{mg} / \mathrm{kg}$ f.w. in muscle of a Bluefin tuna of $137 \mathrm{~cm}$ fork length (body weight $46.5 \mathrm{~kg}$ ) and a maximum value of $2.211 \mathrm{mg} / \mathrm{kg}$ f.w. in a tuna of $252 \mathrm{~cm}$ fork length (body weight $252 \mathrm{~kg}$ ). The average amount of mercury in muscle is $0.660 \mathrm{mg} / \mathrm{kg}$ f.w. with a standard deviation of $0.585 \mathrm{mg} / \mathrm{kg}$ w.w.; the highest concentrations were found in the largest bluefin tuna, with a strong correlation between fork length and mercury in muscle (p $=0.0005$ ), as shown in Figure 4.

Mercury and PCB bioaccumulation mechanisms seem similar; as can be observed in Figure 5 a strong correlation exists between level of these two contaminants in muscle of bluefin tunas $\left(r^{2}=0.4374, p=0.0006\right)$.

\section{Discussion}

Concerining PCBs, if we compare these results with those in the literature on fish from the Mediterranean, we have an indication that the bluefin tuna is one of the fish species with the greatest accumulations of PCBs. Corsolini et al. [28] in 1995 report values of PCBs in bluefin tuna muscle from Egadi Island between 0.170 and 2.2 $\mathrm{mg} / \mathrm{kg}$ wet weight and Kannan et al. [3] in 1999 found 0.197 and $0.363 \mathrm{mg} / \mathrm{kg}$ wet weight of PCBs in bluefin tuna muscle (fork length 149 and $171 \mathrm{~cm}$ respectively) collected off the Ionian coast of Sicily (Italy). These values are very similar to those found in this study in samples caught off the coasts of Sardinia. Giant bluefin tuna (300 - $400 \mathrm{~kg}$ ) collected off the Tyrrhenian coasts of Sicily in 1992 showed still higher concentrations of PCBs, up to $2.2 \mathrm{mg} / \mathrm{kg}$ wet weight [29]; these high values can be attributed to the large size of the specimens and are a further indication of mercury bioaccumulation in tuna. In the year 2012, Focardi [14] reported average values of $0.666 \mathrm{mg} / \mathrm{kg}$ f.w. in muscle of bluefin tunas from the market in Central Italy, while in the same year Focardi 

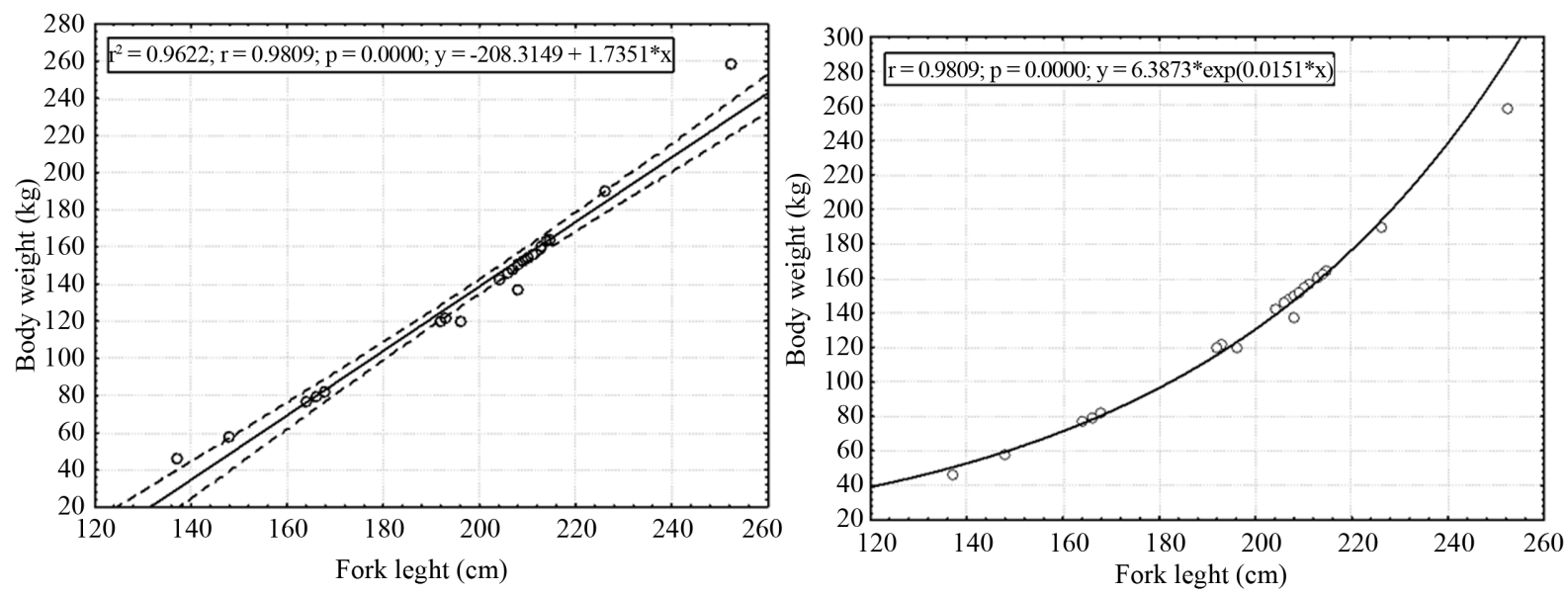

Figure 2. Relationship between fork length and body weight in Bluefin tunas.



Figure 3. Relationship between fork length and PCBs in Bluefin tuna muscle.

and Renzi [30] reported an average value of PCBs of 1.5 $\mathrm{mg} / \mathrm{kg}$ f.w. in bluefin tunas from Ionian Sea. In these studies as well, the highest concentrations were found in the largest bluefin tuna.

Concerning Hg, results reported in this study clearly indicate that numerous samples of bluefin tuna muscle contained more than $0.5 \mathrm{mg} / \mathrm{kg}$ f.w., which is the maximum level set by the European Commission (EC, Regulation n. 1881/2006) for most fish species; six samples had more than $1 \mathrm{mg} / \mathrm{kg}$ f.w., which is the limit for bluefin tuna in this regulation. This data is in keeping with the fact that the Mediterranean Sea has in the recent past shown signs of a geochemical anomaly with regard to mercury, with a few differences among various areas. In organisms from the Tyrrhenian Sea in particular, Hg concentrations are markedly elevated; this region, besides receiving many anthropogenic pollutants, is associated with a large area of cinnabar-rich ores as a result of years of intensive mining, and the weathering of mineralized sediments has evidently increased the concentrations of mercury in the marine environment. Similar mercury-bearing deposits are scattered throughout the Mediterranean basin and can account for high mercury levels in both pelagic and benthic organisms [8-31]. Leonzio et al. [32] report average mercury concentrations in Mullus barbatus from the Northern Tyrrhenian Sea between 110 and $2810 \mathrm{ng} / \mathrm{g}$ f.w. and between 110 and $200 \mathrm{ng} / \mathrm{g}$ f.w. in Engraulis encrasicolus. If we consider tuna, Bernhard and Renzoni [33] report an average of $1.65 \mathrm{mg} / \mathrm{kg}$ f.w. in $T$. thynnus muscle from South 


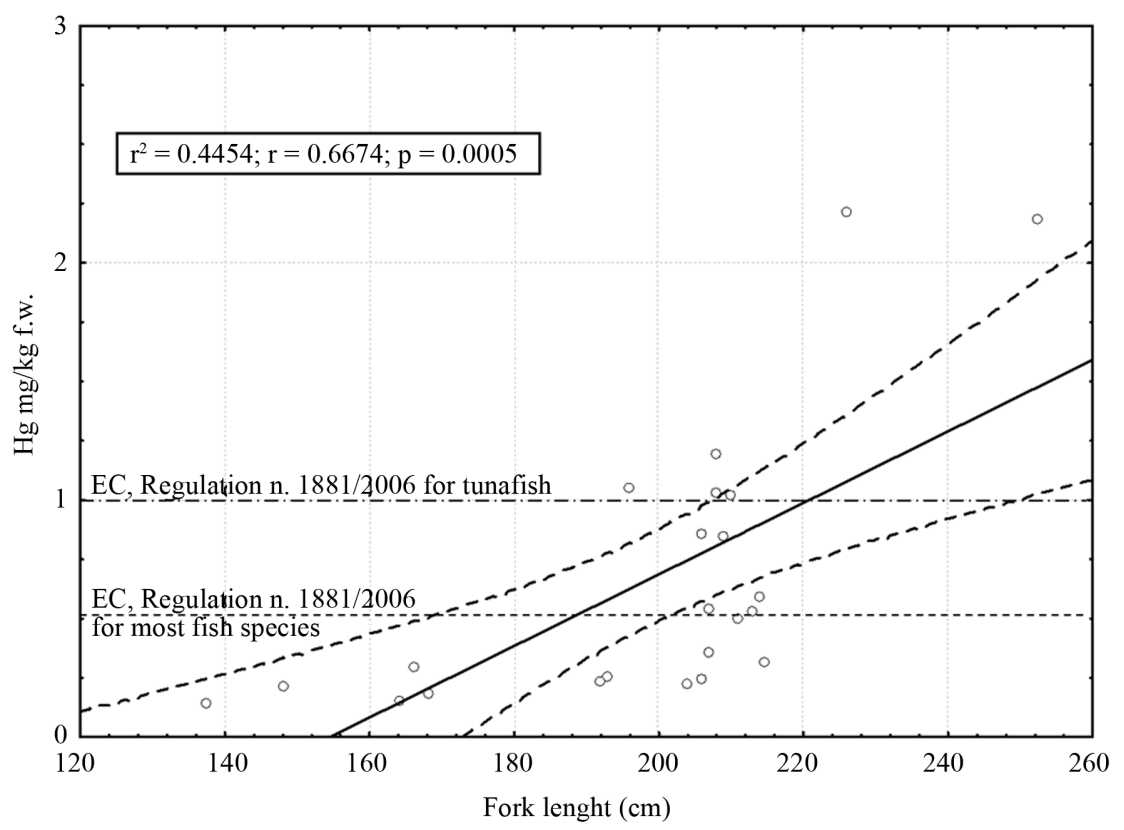

Figure 4. Relationship between fork length and mercury in Bluefin tuna muscle, with maximum level set by the European Commission for fish species.

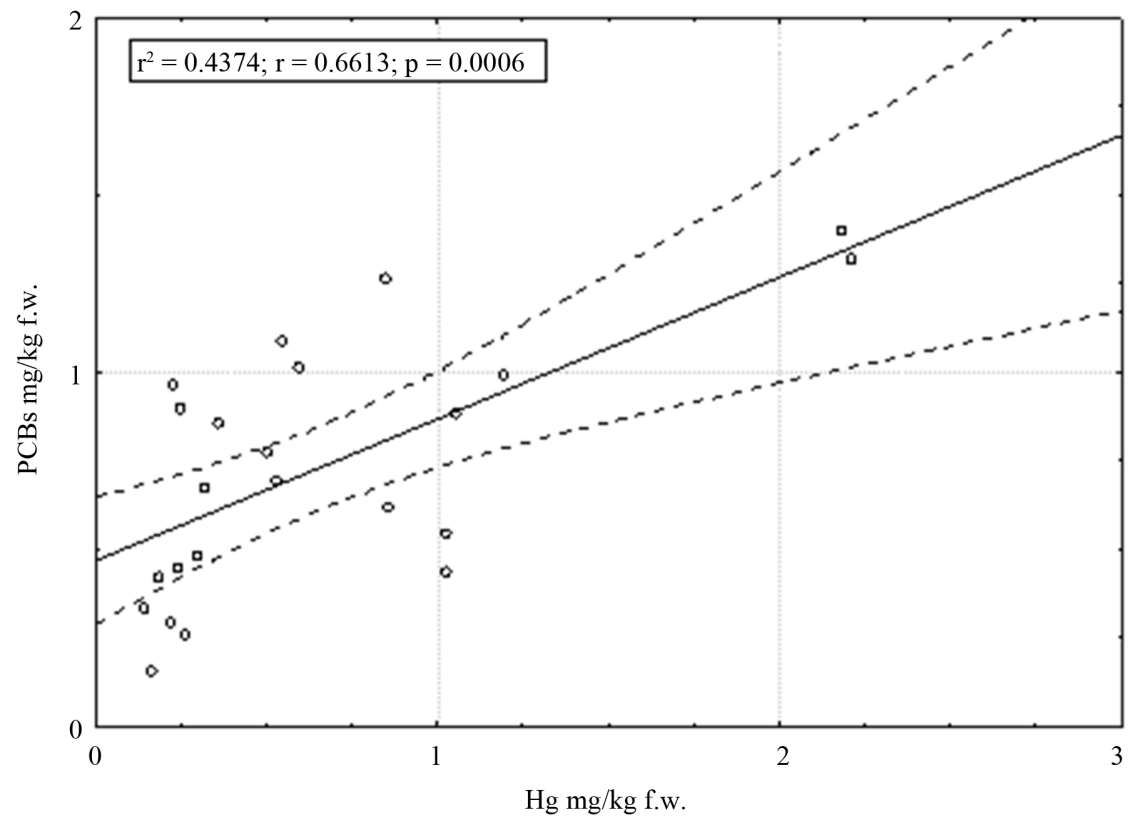

Figure 5. Relationship between mercury and PCBs in Bluefin tuna muscle.

Western Sardinia, with a range between 0.01 and 3.25 $\mathrm{mg} / \mathrm{kg}$. In the muscle of bluefin tuna from the Mediterranean Sea, Storelli et al. [34] report mercury concentrations between 0.16 and $2.59 \mathrm{mg} / \mathrm{kg}$ f.w., and Licata et al. [35] report concentrations of mercury between 2.45 and $4.21 \mathrm{mg} / \mathrm{kg}$ f.w. in muscle of bluefin tuna caught in the Strait of Messina. More recently, Focardi [14] reported in 81 muscle samples of bluefin tuna from the Sienese market an average mercury concentration of $0.452 \mathrm{mg} / \mathrm{kg}$ f.w. $(S D=0.317)$.

The bluefin tuna is one of the fastest pelagic swimmers and may reach speeds of up to $70 \mathrm{~km} / \mathrm{h}$ during migrations over thousands of kilometers. Its metabolism is high, and it is a voracious animal that feeds primarily on schooling fishes [36]. Since diet is clearly the prevalent factor in the accumulation of mercury and PCBs in tuna, we can 
hypothesize that the diet of tuna living in this area of the Mediterranean is fairly homogeneous.

\section{Conclusion}

The results of this study in muscle of bluefin tuna from the Island of Sardinia are consistent with previous studies that have reported considerable levels of contamination by mercury (Hg) and polychlorobiphenyls (PCBs) in this top predator in the Mediterranean marine environment. As the Mediterranean is almost entirely landlocked, its waters have a very low renewal rate of 100 years; this limited water exchange increases the chemical residence time and allows bioaccumulation, making the organisms excessively sensitive to pollution.

Higher values of PCBs (average over $0.7 \mathrm{mg} / \mathrm{kg}$ f.w.) were observed in larger fish, with a strong correlation between PCB levels and fork length. The average amount of mercury in muscle is $0.660 \mathrm{mg} / \mathrm{kg}$ f.w. and mercury values vary between $0.140 \mathrm{f}$.w. and $2.211 \mathrm{mg} / \mathrm{kg}$ f.w., with the highest concentrations found in the largest bluefin tunas.

It is interesting to consider that in recent years, mercury and PCB concentrations found in Mediterranean tuna have been decreasing [14]. This is possibly due to the fact that in the Mediterranean, fish size is gradually being reduced as a result of overfishing (younger organisms are less polluted). In recent years, the possibility that the Mediterranean tuna population is suffering the negative effects of pollution has also been considered; potential reproductive alterations in large pelagic fish in this basin could be linked to the high levels of accumulation of endocrine disruptors in these organisms $[5,7,37]$.

It should in any case be noted that six samples of bluefin tuna muscle, $26 \%$ of the samples examined, contained more than $1 \mathrm{mg} / \mathrm{kg}$ f.w. which is the maximum level set by the European Commission (EC, Regulation n. 1881/ 2006) for this species. Mercury, in particular methylmercury, poses a risk to public health [38]. Taking into account the important nutritional contribution that tuna fish makes to the diet, it is advisable that women of childbearing age, pregnant and breastfeeding women as well as young children strictly limit their consumption of tuna from this area of the Mediterranean.

\section{Acknowledgements}

Authors are grateful to Theresa Davis for the English language revision.

\section{REFERENCES}

[1] W. S. Broecker and R. Gerard, "Natural Radiocarbon in the Mediterranean Sea," Limnology and Oceanography, Vol. 14, No. 6, 1969, pp. 883-888.
[2] K. Kannan, S. Corsolini, J. Falandysz, G. Oehme, S. Focardi and J. P. Giesy, "Perfluoroctanesulfonate and Related Fluorinated Hydrocarbons in Marine Mammals, Fishes and Birds from Coasts of the Baltic and Mediterranean Seas," Environmental Sciences and Technology, Vol. 36, No. 15, 2002, pp. 3210-3216.

[3] K. Kannan, S. Corsolini, T. Imagawa, S. Focardi and J. P. Giesy, "Polychlorinated -Naphthalenes, -Biphenyls, -Dibenzop-Dioxins and -Dibenzofurans in Bluefin Tuna, Swordfish, Cormorants and Barn Swallows from Italy,” Ambio, Vol. 31, No. 3, 2002, pp. 207-211.

[4] P. Stefanelli, A. Ausili, A. Di Muccio, M. C. Fossi, S. Di Muccio, S. Rossi and A. Colasanti, "Organochlorine Compounds in Tissues of Swordfish (Xiphias gladius) from Mediterranean Sea and Azores Islands," Marine Pollution Bulletin, Vol. 49, No. 11-12, 2004, pp. 938-950.

[5] S. Damiano, P. Papetti and P. Menasatti, “Accumulation of Heavy Metals to Assess the Health Status of Swordfish in a Comparative Analysis of Mediterranean and Atlantic Areas,” Marine Pollution Bulletin, Vol. 62, No. 8, 2011, pp. 1920-1925. http://dx.doi.org/10.1016/j.marpolbul.2011.04.028

[6] C. Leonzio, E. Bacci, S. Focardi and A. Renzoni, "Heavy metals in organisms from the Northern Tyrrhenian Sea," Science of the Total Environment, Vol. 20, No. 3, 1981, pp. 131-146. http://dx.doi.org/10.1016/0048-9697(81)90059-0

[7] S. Corsolini, C. Guerranti, G. Perra and S. Focardi, "Polybrominated Diphenyl Ethers, Perfluorinated Compounds and Chlorinated Pesticides in Swordfish (Xiphias gladius) from the Mediterranean Sea," Environmental Sciences and Technology, Vol. 42, No. 12, 2008, pp. 43444349. http://dx.doi.org/10.1021/es703057f

[8] A. Renzoni, M. Bernhard, R. Sara and M. Stoeppler, "Comparison between the Hg body burden of Thunnus thynnus from the Mediterranean and the Atlantic," IVes Journées Estud. Pollut, Antalya C.I.E.S.M., Antalia, 1978, pp. 255-260.

[9] C. Leonzio, E. Bacci, S. Focardi and A. Renzoni, "Heavy Metals in Organisms from the Northern Tyrrhenian Sea," Science of the Total Environment, Vol. 20, No. 2, 1981, pp. 131-146. http://dx.doi.org/10.1016/0048-9697(81)90059-0

[10] A. Renzoni, S. Focardi, C. Fossi, C. Leonzio and J. Mayol, "Comparison between Concentration of Mercury and Other Contaminants in Eggs and Tissues of Adults of Cory's Shearwater (Calonectris diomedea) Collected on Atlantic and Mediterranean Islands," Environmental Pollution Series A, Vol. 40, No. 1, 1986, pp. 17-35. http://dx.doi.org/10.1016/0143-1471(86)90055-3

[11] C. Leonzio, C. Fossi and S. Focardi, "Lead, Mercury, Cadmium and Selenium in Two Species of Gull Feeding on Dumps and in Marine Areas," Science of the Total Environment, Vol. 57, 1986, pp. 121-127. http://dx.doi.org/10.1016/0048-9697(86)90017-3

[12] K. Kannan, S. Tanabe, A. Borrell, A. Aguilar, S. Focardi and R. Tatsukawa, "Isomer-Specific Analysis and Toxic Evaluation of Polychlorinated Biphenyls in Striped Dol- 
phins Affected by an Epizootic in the Western Mediterranean Sea," Archives of Environmental Contamination and Toxicology, Vol. 25, No. 2, 1993, pp. 227-233. http://dx.doi.org/10.1007/BF00212134

[13] A. Borrell, A. Aguilar, S. Corsolini and S. Focardi, "Evaluation of the Toxicity and Sex-Related Variation of PCB Levels in Mediterranean Striped Dolphins Affected by an Epizootic," Chemosphere, Vol. 32, No. 12, 1996, pp. 2359-2369. http://dx.doi.org/10.1016/0045-6535(96)00143-9

[14] S. Focardi, "Levels of Mercury and Polychlorobiphenyls in Commercial Food in Siena Province (Tuscany, Italy) in the Period 2001-2010,” Microchemical Journal, Vol. 105, 2012, pp. 60-64. http://dx.doi.org/10.1016/j.microc.2012.01.013

[15] S. Corsolini, A. Ademollo, T. Romeo, S. Greco, S. Focardi, "Persistent Organic Pollutants in Edible Fish: A Human and Environmental Health Problem," Microchemical Journal, Vol. 79, No. 1-2, 2005, pp. 115-123. http://dx.doi.org/10.1016/j.microc.2004.10.006

[16] M. M. Storelli, R. Giacominelli-Stuffler, A. Storelli and G. O. Marcotrigiano, “Accumulation of Mercury, Cadmium, Lead and Arsenic in Swordfish and Bluefin Tuna from the Mediterranean Sea: A Comparative Study," $M a-$ rine Pollution Bulletin, Vol. 50, No. 9, 2005, pp. 9931018. http://dx.doi.org/10.1016/j.marpolbul.2005.06.041

[17] M. M. Storelli, R. Giacominelli-Stuffler and G. O. Marcotrigiano, "Total and Methylmercury Residues in TunaFish from the Mediterranean Sea," Food Additives \& Contaminants, Vol. 19, No. 8, 2002, pp. 715-720. http://dx.doi.org/10.1080/02652030210153569

[18] S. Focardi, C. Fossi, C. Leonzio and R. Romei, "PCB Congeners, Hexachlorobenzene, and Organochlorine Insectidices in Human Fat in Italy," Bulletin of Environmental Contamination and Toxicology, Vol. 36, No. 1, 1986, pp. 644-650.

http://dx.doi.org/10.1007/BF01623563

[19] S. Focardi and R. Romei, "Fingerprint of Polychlorinated Biphenyl Congeners in Samples of Human Subcutaneous Adipose Tissue,” Chemosphere, Vol. 16, No. 10-12, 1987, pp. 2315-2320. http://dx.doi.org/10.1016/0045-6535(87)90288-8

[20] S. Corsolini, S. Focardi, K. Kannan, S. Tanabe and R. Tatsukawa, "Isomer-Specific Analysis of 250 Polychlorinated Biphenyls and 2,3,7,8-Tetrachlorodibenzo-pDioxin Equivalents (TEQs) in Red Fox and Human Adipose Tissue from Central Italy," Archives of Environmental Contamination and Toxicology, Vol. 29, No. 1, 1995, pp. 61-68. http://dx.doi.org/10.1007/BF00213088

[21] M. Mariottini, S. Aurigi and S. Focardi, "Congener Profile and Toxicity Assessment of Polychlorinated Biphenyls in Human Adipose Tissue of Italians and Chileans," Microchemical Journal, Vol. 67, No. 1-3, 2000, pp. 63-71. http://dx.doi.org/10.1016/S0026-265X(00)00100-4

[22] M. Mariottini, C. Guerranti, S. Aurigi, I. Corsi and S. Focardi, "Pesticides and Polychlorinated Biphenyl Residues in Human Adipose Tissue," Bulletin of Environmental Contamination and Toxicology, Vol. 68, No. 1,
2002, pp. 72-78.

[23] C. Guerranti, M. Palmieri, M. Mariottini and S. E. Focardi, "Persistent Organic Pollutants in Human Milk from Central Italy: Levels and Time Trends,” ISRN Toxicology, Vol. 2011, 2011, Article ID 107514, 6 p.

[24] J. M. Formentin, "ICCAT Manual, Ch.2.1.5: Atlantic Bluefin Tuna,” 2006, pp. 93-111.

[25] J. Viñas, A. Gordoa, R. Fernández-Cebrián, C. Pla, Ü. Vahdet and R. M. Araguas, "Facts and Uncertainties about the Genetic Population Structure of Atlantic Bluefin tuna (Thunnus thynnus) in the Mediterranean. Implications for Fishery Management," Reviews in Fish Biology and Fisheries, Vol. 21, No. 3, pp. 527-541. http://dx.doi.org/10.1007/s11160-010-9174-6

[26] C. Reeb, "Genetic Discontinuity of Big Fish in a Small Sea,” PNAS, Vol. 107, No. 6, 2010, pp. 2377-2378. http://dx.doi.org/10.1073/pnas.0914639107

[27] G. Riccioni, M. Landi, G. Ferrara, I. Milano, A. Cariani, L. Zane, M. Sella, G. Barbujani and F. Tinti, "SpatioTemporal Population Structuring and Genetic Diversity Retention in Depleted Atlantic Bluefin Tuna of the Mediterranean Sea,” PNAS, Vol. 107, No. 5, 2010, pp. 21022107. http://dx.doi.org/10.1073/pnas.0908281107

[28] S. Corsolini, S. Focardi, K. Kannan, S. Tanabe, A. Borrell and R. Tatsukawa, "Congener Profile and Toxicity Assessment of Polychlorinated Biphenyls in Dolphins, Sharks and Tuna Fish from Italian Coastal Waters,” Marine Environmental Research, Vol. 40, No. 1, 1995, pp. 33-53. http://dx.doi.org/10.1016/0141-1136(94)00003-8

[29] J. M. Fromentin, “The East-Atlantic and Mediterranean Bluefin Tuna Stock Management: Uncertainties and Alternatives," Scientia Marina, Vol. 67, No. S1, 2003, pp. 51-62.

[30] S. Focardi and M. Renzi, "Polybrominated Diphenyl Ethers and Polychlorobiphenyls in Fish from the Ionian Sea (Western Mediterranean)," Journal of Environmental Protection, Vol. 3, No. 3, 2012, pp. 135-140. http://dx.doi.org/10.4236/jep.2012.32017

[31] M. Stoeppler, M. Bernhard, F. Backhaus and E. Schulte, "Comparative Studies on Trace Metals in Marine Biota. I. Mercury in Marine Organisms from Western Italian Coast, the Strait of Gibraltar and the North Sea," Science of the Total Environment, Vol. 13, No. 3, 1979, pp. 209-223. http://dx.doi.org/10.1016/0048-9697(79)90102-5

[32] C. Leonzio, E. Bacci, S. Focardi and A. Renzoni, "Heavy Metals in Organisms from the Tyrrhenian Sea," Science of the Total Environment, Vol. 20, No. 2, 1981, pp. 131146. http://dx.doi.org/10.1016/0048-9697(81)90059-0

[33] M. Bernhard and A. Renzoni, "Mercury Concentration in Mediterranean Marine Organisms and Their Environment: Natural or Anthropogenic Orgin?” Thalassia Jugoslavica, Vol. 13, 1977, pp. 265-300.

[34] M. M. Storelli, R. Giacomelli Stuffler and G. O. Marcotrigiano, "Total and Methylmercury Residues in TunaFish from the Mediterranean Sea," Food Additives and Contaminants, Vol. 19, No. 8, 2002, pp. 715-720. http://dx.doi.org/10.1080/02652030210153569 
[35] P. Licata, D. Trombetta, M. Cristani, C. Naccari, D. Martino, M. Calò and F. Naccari, "Heavy metals in lliver and muscle of bluefin tuna (Thunnus thynnus) caught in the Strait of Messina (Sicily, Italy)," Environmental Monitoring and Assessment, Vol. 107, No. 1, 2005, pp. 239248. http://dx.doi.org/10.1007/s10661-005-2382-1

[36] B. C. Chase, "Differences in Diet of Atlantic Bluefin Tuna (Thunnus thynnus) at Five Seasonal Feeding Grounds on the New England Continental Shelf,” Fishery Bulletin, Vol. 100, No. 2, 2002, pp. 168-180.

[37] M. C. Fossi, S. Casini, L. Marsili, S. Ancora, G. Mori, G.
Neri, T. Romeo and A. Ausili, "Evaluation of Ecotoxicological Effects of Endocrine Disrupters during a Four Year Survey of the Mediterranean Population of Swordfish (Xiphias gladius)," Marine Environmental Research, Vol. 58, No. 2-5, 2004, pp. 425-429. http://dx.doi.org/10.1016/j.marenvres.2004.03.026

[38] EFSA, "Opinion of the Scientific Panel on Contaminants in the Food Chain on a Request from the Commission Related to Mercury and Methylmercury in Food," The EFSA Journal, Vol. 34, 2004, pp. 1-14. 